'notre mère' ou la 'vieille mère'), puis les cours d'eau, les sources, les collines; bienfaisantes, elles protègent la collectivité et la vie de famille en lui dispensant la prospérité. Au contraire les dieux empruntés aux autres tribus ont souvent mauvais caractère.

Mais toutes les divinités ne demeurent bien intentionnées que si l'on observe leurs lois, leurs 'tabous', et si des offrandes leur sont faites. La moindre négligence peut exciter leur colère et leur vengeance. Les relations avec elles sont donc fondées sur l'application bien réglée du 'do ut des', il n'y entre pour les fidèles aucune règle de morale.

Dieu-Ciel lui-même est uni à un phénomène de la nature, en fait, le ciel visible. Pourtant il a une situation spéciale, il est au-dessus de tout et partout. 'As-tu jamais vu les limites du ciel?' demandait un Ewe. Il est conçu personnellement comme les divinités locales, mais sa puissance et son domaine dépassent de beaucoup ceux d'une simple divinité tribale. Il est la cause de toute chose. Les divinités locales sont ses enfants et tiennent leur pouvoir de lui seul. Il est le créateur, le Maître et le Soutien du Monde et de tout ce qui est dessus. Les qualités caractéristiques sont: puissance, droiture et bonté; elles sont exprimées dans quantité de louanges, proverbes et chansons. 'En lui-même et extérieurement le papillon loue Dieu'; 'Riches et pauvres sont la création de Dieu'; 'Tous les hommes sont les enfants de Dieu, aucun ne descend de la terre'; 'Celui que Dieu ne tue pas ne meurt jamais'; 'Si tu veux parler à Dieu, adresse-toi au vent'; 'Laissez Dieu mener la bataille et reposez votre tête dans vos mains'; 'Ceux que nous ne pouvons atteindre nous les trouverons dans les mains de Dieu.'

Les divinités locales châtient l'homme qui transgresse leurs ordres, de Dieu on attend la punition de l'immoralité. Il accueille l'opprimé et lui rend justice; dans le besoin chacun peut se tourner vers lui, il est le dernier recours 'et nous accorde sa pitié tous les jours', 'c'est un Dieu plein de bonté.' Son éloignement, sson universalité, sa bonté ont sans doute rendu ses représentations quelque peu indéterminées et estompées. Il ne réclame aucun sacrifice et ne saurait être influencé par des offrandes; il reste en dehors du culte. La croyance en lui est souvent une conviction, en quelque sorte théorique, qu'il existe une organisation du monde aussi juste que bonne, guidant le destin de l'ensemble et de l'individu.

\title{
CONCEPTIONS OF GOD FOUND IN WEST AFRICA
}

\section{By Diedrich WestermanN}

$$
\text { (See p. r 89) }
$$

IN Africa we find three groups of beings conceived as being more or less imbued with personality and the objects of religious veneration: 1 . individual tutelary spirits; 2. local deities; 3. the God of Heaven. The personal 
tutelary or guardian spirit, best known by the name okra, used on the Gold Coast and in the neighbouring districts, is a being which enters the body of a man at his birth, and remains either in him or near him as long as life lasts. This being determines his character and consequently his destiny; if a man is wicked, it is because he has a 'black' okra. As a rule, however, this spirit protects, advises, and helps the man. It warns him of danger and preserves him from it; and any special good fortune, or success in a man's career are due to the okra. Gratitude to it is expressed by sacrificial gifts, and a small hut is built in which to place the gifts. The close identity between the okra and the man in which it lives can be seen in the following Ewe custom; when a young man marries, he has to take into consideration that before he entered on his earthly existence he had already been married as an olera in the world of spirits, and that he had left his wife in that world. As his former wife might be jealous of his earthly wife, the man builds a small hut dedicated to her and in it he places a small part of each present he offers his earthly betrothed or wife. Before the okra set out for the earth, it promised its associates which stayed behind that it would return within a specified time. When the okra is due to return, the man falls ill, and when he dies the okra leaves him in order to return to the world of spirits. Later on it is possible that God may allow it to be born again in the body of a grandchild of its former possessor.

Local deities form the chief objects of worship. Most of them are the incorporation of natural objects or of natural phenomena, such as the earth, rivers, lakes, the sea, lagoons, mountains, rocks, springs, big trees, thunder and lightning; rarely animals. The gods, however, are never identified with these objects; they are invisible and the objects in question are inhabited by them temporarily, they serve as places to which offerings can be brought and where gifts can be asked for. Besides these gods representing the powers of nature, there are others, for instance: gods of war, of peace, of the year, of the harvest, of the fruits of the field, of the forge, of huntsmen, gods of prophecy, gods of disease. Idols are often set up in their honour, and shrines at which they can be worshipped. As a rule a priest is set apart for each deity, and it is he who arranges for communication with the deity. The priest is often selected by the deity, in other words a state of ecstasy is induced in the priest. The deity receives its power from the God of Heaven by whom it is generally considered to have been created; and it is the God of Heaven who delegates to the deity the administration of a definite sphere of living beings. Deities exist which are honoured by an individual, a family, a village or even by a whole tribe. The old native tribal deities are those which are most honoured, above all, for instance, the earth (some tribes call it 'our mother', or 'the ancient woman') rivers, springs, hills, they are the beneficent guardians who dispense blessings, the promoters of the community system and of family life; deities taken over from other tribes are often evil. But all these deities are 
benevolent only as long as their laws and their taboos are observed, and as long as gifts are offered up to them. Neglect of any kind may arouse their anger and revenge. Communication with them is based on a regular system of give and take, but not on the moral conduct of the worshippers.

The God of Heaven is also connected with a natural body, namely with the visible heaven. But this God holds a unique position, he is above everything and is everywhere. 'Have you ever seen the limits of the heavens?' said an Ewe Native. Just as in the case of the local deities, so too the conception of the God of Heaven is a personal one, but his significance and the extent of his power are far greater than that of a tribal deity. Everything owes its existence to him. Local deities are his children, they derive their power from him. He is the creator, the guide and preserver of the world and of all that is in the world. His characteristic qualities are power, justice and goodness, and they find expression in a number of 'praise names', sayings and songs. 'The creation of the butterfly is to the glory of God,' 'Rich and poor are the work of the Almighty,' 'All human beings are God's children, none of them are the earth's children,' 'He whom God does not kill will not die,' 'If you want to speak to God, speak to the wind,' 'Leave the battle to God and rest your head in your hands,' 'Those whom we cannot catch we leave in the hands of God.' Local deities punish those who break their commands, it is God who punishes breaches of ethical law. He takes pity on those who are oppressed and he obtains justice for them, and those who are in trouble can turn to him, he is their last resort and 'he has mercy on us all our days', 'he is a good God.' His remoteness, his universality and his goodness have, however, resulted in the conceptions of him being somewhat indefinite and shadowy. He does not require sacrifice and is not influenced by it; he is not influenced by worship. Belief in him is the conviction, frequently somewhat theoretical, of a just and benevolent world order, which directs the destiny of humanity as a whole and the destiny of the individual. 